\title{
ANALISIS KADAR HEMOGLOBIN PADA PASIEN PENDERITA GAGAL GINJAL KRONIK
}

\author{
Hendra R. Akhdiyat \\ Universitas Pendidikan Ganesha \\ Singaraja, Indonesia \\ e-mail: hendra89@gmail.com
}

\begin{abstract}
Abstrak
Penelitian ini bertujuan untuk mengetahui (1) kadar hemoglobin pada darah pasien penderita gagal ginjal kronik, (2) persentase penderita gagal ginjal kronik yang megidap anemia. Adapun subjek dari penelitian ini adalah pasien penderita gagal ginjal koronik (GGK), sedangkan Objeknya adalah kadar hemoglobin darah pasien penderita GGK. Data diperoleh dengan mengukur sampel darah pasien penderita gagal ginjal kronik (GGK) dengan menggunakan alat Sysmex $K X-21$. Jumlah pasien penderita GGK yang diukur sampel darahnya sebanyak 23 orang (7 orang wanita dan 16 orang laki-laki) Data dianalisis menggunakan metode deskriptif. Hasil analisis penelitian ini menunjukkan, bahwa rentangan kadar hemoglobin dalam darah pasien penderita GGK wanita adalah $3-8 \mathrm{~g} / \mathrm{dL}$, sedangkan pada lakilaki $5-12 \mathrm{~g} / \mathrm{dL}$. Persentase penderita GGK yang mengidap anemia adalah $100 \%$, dengan rincian masing-masing 2 orang mengidap anemia berat dan ringan, sedangkan yang lainnya (19 orang) mengidap anemia sedang. Anemia terjadi karena fungsi ginjal pada penderita GGK tidak bekerja dengan baik, sehingga ginjal kurang mampu fungsi ginjalnya tidak bekerja dengan baik, termasuk dalam memproduksi hormon eritropoeitin, yang berfungsi dalam pembentukan sel darah merah. Berkurangnya produksi hormon tersebut menyebabkan produksi sel darah merah menjadi berkurang, sehingga secara langsung menyebabkan menurunya kadar hemoglobin dalam darah.
\end{abstract}

Kata kunci: SPMI, sekolah model, konteks, input, proses, produk

\begin{abstract}
This study aims to determine (1) the level of hemoglobin in the blood of patients with chronic renal failure, (2) the percentage of patients with chronic kidney failure who have anemia. The subjects of this study were patients with coronic renal failure (CRF), while the object was the blood hemoglobin levels of patients with CRF. Data were obtained by measuring blood samples from patients with chronic renal failure (CRF) using the Sysmex KX-21 instrument. The number of patients with CRF whose blood samples were measured was 23 people ( 7 women and 16 men). Data were analyzed using descriptive methods. The results of the analysis of this study indicate that the range of hemoglobin levels in the blood of female patients with CRF is 3$8 \mathrm{~g} / \mathrm{dL}$, while in men it is $5-12 \mathrm{~g} / \mathrm{dL}$. The percentage of CRF sufferers who have anemia is $100 \%$, with details of each 2 people suffering from severe and mild anemia, while the other (19 people) have moderate anemia. Anemia occurs because the kidney function in people with chronic kidney disease does not work properly, so the kidneys are not able to function properly, including in producing the hormone erythropoeitin, which functions in the formation of red blood cells. The reduced production of these hormones causes the production of red blood cells to decrease, which leads to a decrease in hemoglobin levels in the blood.
\end{abstract}

Keywords: gagal ginjal kronik, hormon eritropoeitin, kadar hemoglobin, anemia. 


\section{Pendahuluan}

Setiap hewan memiliki alat eksresi tersendiri, termasuk manusia sebagai jenis mamalia. Manusia memiliki beberapa macam alat ekskresi, yang berfungsi untuk mengeluarkan zat-zat sisa hasil metabolisme yang tidak terpakai lagi oleh tubuh (Djamhur, dkk. 1994). Dari beberapa jenis alat ekskresi yang dimiliki manusia, ginjal (ren) merupakan alat ekskresi yang paling utama. Selain sebagai alat ekskresi, ginjal juga mempunyai fungsi sebagai pengatur keseimbangan cairan tubuh, pengatur konsentrasi garam dalam darah, dan pengatur keseimbangan $\mathrm{pH}$ darah. Ginjal juga memiliki peranan yang cukup besar dalam proses pembentukan sel darah merah (eritrosit). Dalam hal ini, ginjal menghasilkan hormon eritropoeitin yang digunakan untuk merangsang pembentukan eritrosit. Hormon tersebut hanya dihasilkan oleh ginjal. Jika seseorang menderita penyakit gagal ginjal kronik, maka hormon eritropoeitin yang dihasilkannya akan berkurang. Akibatnya, jumlah eritrosit yang dibentuk oleh tubuh pun akan menjadi berkurang.

Menurut Nico A. Lumenta (1992: 72), jumlah pasien gagal ginjal di Indonesia setiap tahunnya bertambah tidak kurang dari 20 pasien per sejuta penduduk. Dalam tingkat lokal, catatan medis yang ada di Laboratorium Patologi Klinik RSUD Kabupaten Buleleng menunjukkan adanya peningkatan jumlah pasien dari tahun ke tahun yang melakukan pemeriksaan fungsi ginjalnya. Dari catatan itu juga diperoleh keterangan, bahwa rata-rata pasien yang telah diperiksa, $20 \%$ di antaranya diperkirakan mengidap penyakit ginjal akut, dan $5 \%$ lainnya mengidap gagal ginjal kronik. Kerusakan ginjal yang kronik tersebut dapat ditimbulkan oleh berbagai macam penyebab, dan tidak terlepas pula dari kebiasaan buruk dari pasein tersebut.

Mengingat salah satu fungsi ginjal adalah memproduksi hormon eritropoeitin yang berguna dalam pembentukan sel-sel darah merah, yang secara langsung berhubungan dengan kadar hemoglobinnya, dan mengingat peran hemoglobin sebagai pengangkut oksigen ke seluruh jaringan tubuh, maka dipandang perlu untuk melakukan penelitian berkaitan dengan kadar hemoglobin pada penderita gagal ginjal.

\section{Metode}

Penelitian Penelitian ini tergolong penelitian deskriptif, yang dilakukan dengan tujuan untuk mengetahui kadar hemoglobin pasien penderita gagal ginjal kronik (GGK) dan persentase penderita GGK yang mengidap anemia. Rancangan kegiatan secara utuh dapat dilihat pada Gambar 1.

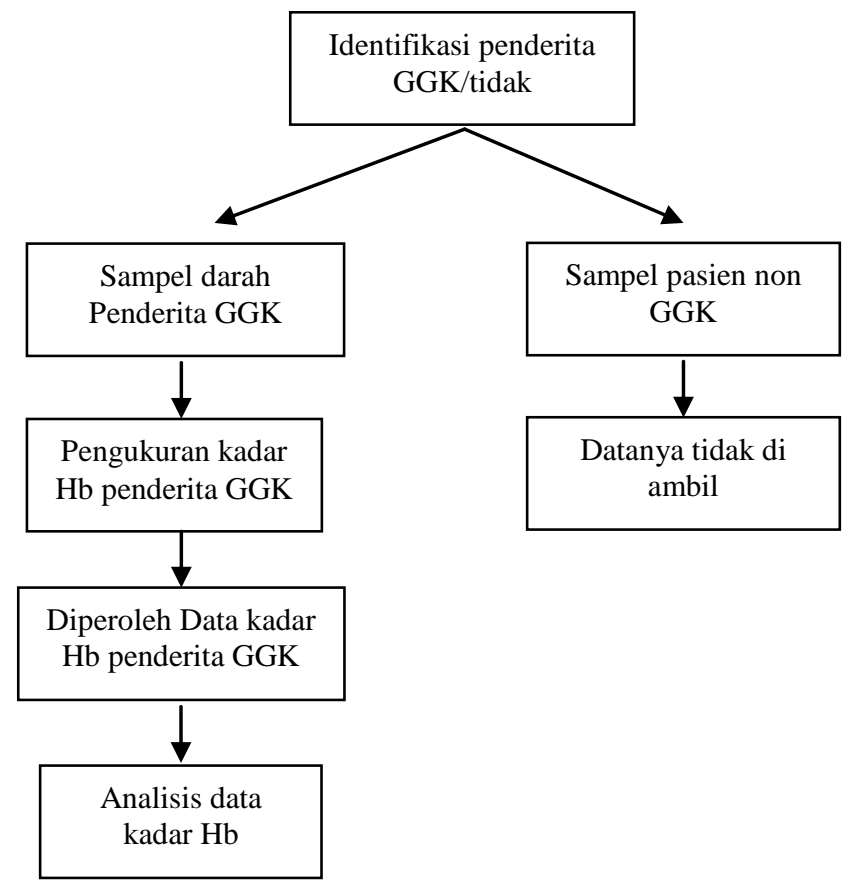

Gambar 1. Bagan Rancangan Penelitian 
Penelitian kadar hemoglobin pada pasien gagal ginjal kronik ini sepenuhnya dilakukan di Laboratorium Patologi Klinik RSUD Kabupaten Buleleng. Subjek penelitian ini adalah pasien penderita gagal ginjal kronik, sedangkan objek penelitiannya adalah kadar hemoglobin dalam darah pasien tersebut.

Jenis data yang diperoleh dalam penelitian ini adalah data kuntitatif tentang kadar hemoglobin pasien penderita gagal ginjal kronik. Kadar hemoglobin tersebut ditentukan dengan melakukan pemeriksaan darah lengkap menggunakan alat Sysmex $K X-21$.

Alat yang digunakan dalam penelitian ini adalah Sysmex $K X-21$, roller mixer, dan tabung darah lengkap, sedangkan bahan yang digunakan adalah darah pasien penderita GGK dan zat anti koagualan EDTA.

Sebelum proses pengukuran darah lengkap pasien penderita gagal ginjal kronik (GGK) dilakukan, terlebih dahulu dilakukan pengklasifikasian pasien yang menderita gagal ginjal. Dalam hal ini pasien penderita GGK dapat ditentukan dengan melihat ruangan tempat pasien dirawat (untuk pasien penderita GGK biasanya berasal dari ruangan hemodialisis). Darah pasien GGK diambil kemudian dimasukkan dalam tabung darah lengkap yang berisi zat anti koagulan EDTA.

Data kadar hemoglobin pasien penderita GGK diperoleh dengan melakukan pengukuran sampel darah penderita menggunakan alat Sysmex $K X-21$ dengan prosedur pemeriksaan sebagai berikut:

1. Alat Sysmex KX-21 dihidupkan dengan menekan tombol ON/OFF pada bagian samping kanan alat.

2. Setelah selesai, alat akan menunjukkan keadaan ready, dan siap dipakai.

3. Sebelum dilakukan pengukuran terhadap sampel darah pasien penderita GGK, terlebih dahulu darah kontrol harus dimasukkan ke dalam alat untuk diukur (sebagai standar).

4. Sampel darah pasien yang ada dalam tabung darah lengkap, sebelum diukur terlebih dahulu diputar dengan alat roller mixer selama kurang lebih 10 menit.

5. Selanjutnya sampel darah pasien GGK tersebut siap untuk diukur.

6. Sampel darah pasien penderita GGK dimasukkan ke dalam alat (alat secara otomatis akan melakukan analisa)

7. Data hasil analisa akan terlihat pada layar monitor alat Sysmex KX-21.

8. Data hasil analisa tersebut selanjutnya di transfer ke komputer.

9. Data dicetak dengan printer laser jet.

10.Diperoleh hasil analisis darah lengkap.

11.Data kadar hemoglobin pasien penderita GGK di catat.

Analisis data dilakukan setelah selesai mengadakan pengumpulan data. Metode analisis yang digunakan untuk memecahkan masalah penelitian ini adalah metode deskriptif, yang menggambarkan kadar hemoglobin pada penderita GGK. Data tersebut kemudian dibandingkan dengan standar WHO untuk menentukan apakah penderita GGK tersebut mengidap anemia atau tidak. Selanjutnya berdasarkan ketentuan yang dikutip dari Algooth Putranto dalam artikelnya pada situs http://cyberwomen.cbn.net.id/detil.aspa?kategori=mhother and newsno=985, maka anemia dapat dikalsifikasikan menjadi 3 golongan, yaitu ringan, sedang, dan berat.

\section{Hasil dan Pembahasan}

\section{A. Kadar Hemoglobin Penderita Ggk}

Berdasarkan data hasil penelitian kadar hemoglobin terhadap 23 orang pasien penderita gagal ginjal kronik (GGK) yang dilakukan di Laboratorium Patologi Klinik RSUD Kabupaten Buleleng diketahui, bahwa rentangan kadar hemoglobin pasien penderita gagal ginjal kronik berkisar antara $3-12 \mathrm{~g} / \mathrm{dL}$. Sedangkan, kadar hemoglobin orang normal berkisar antara $14-$ $18 \mathrm{~g} / \mathrm{dL}$. Hal itu berarti kadar hemoglobin pasien penderita gagal ginjal berada di bawah kadar normal. Penurunan kadar hemoglobin pada penderita gagal ginjal kronik tersebut disebabkan oleh banyak faktor, seperti defesiensi hormon eritropoeitin, defisiensi besi, berkurangnya masa hidup sel darah merah, hiperparatiroidisme berat, inflamasi akut atau kronik, infeksi, toksisitas aluminium, defisiensi asam folat dan hipotriroidisme. Akan tetapi, penyebab utama terjadinya penurunan kadar hemoglobin tersebut adalah defisiensi hormon eritropoeitin.

Hormon eritropoeitin ini diproduksi oleh sel kortikal interstisial di sekitar tubulus proksimal (peritubular) ginjal. Kerusakan ginjal yang kronik menyebabkan kerja ginjal kurang optimal terutama dalam memproduksi hormon eritropoeitin. Berkurangnya volume hormon tersebut 
dalam tubuh menyebabkan terganggunya pembentukan sel darah merah, yang secara langsung menyebabkan penurunan kadar hemoglobin dalam darah.

Tinggi rendahnya penurunan kadar hemoglobin pada penderita gagal ginjal ditentukan oleh tingkat kerusakan ginjalnya, dan tidak lepas pula dari aktivitas yang dilakukannya. Semakin tinggi tingkat kerusakan ginjal seseorang, atau semakin berat aktivitas yang dilakukan oleh seorang penderita gagal ginjal, maka semakin tinggi pula penurunan kadar hemoglobin dalam darahnya.

\section{B. Anemia Pada Penderita Ggk}

Dari data hasil penelitian tentang kadar hemoglobin penderita gagal ginjal kronik, diperoleh rentangan kadar hemoglobin darah pasien berdasarkan jenis kelaminnya yaitu pada wanita $3-8 \mathrm{mg} / \mathrm{dl}$, sedangkan pada laki-laki 5-12 $\mathrm{mg} / \mathrm{dL}$. Menurut WHO, kadar hemoglobin orang yang dinyatakan mengidap anemia adalah wanita dengan kadar hemoglobin kurang dari $12 \mathrm{mg} / \mathrm{dL}$ dan laki-laki dengan kadar hemoglobin kurang dari $14 \mathrm{mg} / \mathrm{dl}$ ), berdasarkan ketentuan tersebut dapat dihitung persentase penderita gagal ginjal kronik (GGK) yang mengidap anemia

Dari hasil pemeriksaan darah lengkap pasien penderita GGK (sebanyak 23 orang), baik laki-laki maupun wanita semuanya dinyatakan mengidap anemia. Walaupun rata-rata mereka mengidap anemia, tetapi jenis anemia yang dideritanya bermacam-macam, sesuai dengan tingkat penurunan kadar hemoglobinnya. Bila penderita gagal ginjal kronik tersebut memiliki kadar hemoglobin $9-11 \mathrm{~g} / 100 \mathrm{~mL}$, maka digolongkan ke dalam anemia ringan. Bila kadar hemoglobinnya $6-8 \mathrm{~g} / 100 \mathrm{~mL}$, maka masuk ke dalam anemia sedang, selanjutnya yang kadar hemoglobinnya berada di bawah $6 \mathrm{~g} / 100 \mathrm{~mL}$, tergolong anemia berat (Putranto, Algooth: 2005). Berdasarkan data di depan, pasien penderita GGK yang mengidap anemia jenis berat dan ringan masing-masing berjumlah dua orang, sedangkan yang lainnya (19 orang) termasuk anemia jenis sedang.

Jenis anemia yang paling dikhawatirkan adalah anemia golongan berat. Penderita GGK yang mengidap anemia berat biasanya memperlihatkan gejala pucat pada tangan, wajah, dan kakinya; kurang bergairah, sakit kepala, mudah marah, serta cepat lelah. Pada tingkat lanjut penderita tidak mampu berkonsentrasi, sangat rentan terhadap infeksi, menampakkan perubahan bentuk kuku, seperti sendok dan rapuh, pecah-pecah pada sudut mulut, dan sulit menelan.

Timbulnya gejala-gejala tersebut di atas dakibatkan oleh tidak normalnya kadar hemoglobin dalam darah. Seperti diketahui, setiap jaringan tubuh membutuhkan oksigen dalam melakukan segala aktivitasnya. Suplai oksigen ke dalam seluruh jaringan tubuh dilakukan oleh hemoglobin. Hemoglobin termasuk protein yang mengandung besi $(\mathrm{Fe})$, sehingga dapat mengikat oksigen dari udara pada saat kita melakukan pernafasan. Pengikatan oksigen oleh hemoglobin membentuk $\mathrm{HbO}_{2}$. Selanjutnya, $\mathrm{HbO}_{2}$ dialirkan ke seluruh jaringan tubuh oleh darah. Dengan demikian, berkurangnya kadar hemoglobin akan menyebabkan kemampuan sel darah merah untuk membawa oksigen ke seluruh tubuh menjadi berkurang. Akibatnya, tubuh kekurangan pasokan oksigen, sehingga tubuh cepat lemas dan lelah.

\section{Simpulan dan Saran}

1. Tujuan Kadar hemoglobin pasien penderita gagal ginjal kronik yang diperiksa di Laboratorium Patologi Klinik RSUD Kabupaten Buleleng berkisar pada rentangan 3-12 $\mathrm{g} / \mathrm{dL}$.

2. Persentase pasien penderita gagal ginjal kronik yang mengidap anemia berdasarkan ketetapan WHO adalah sebanyak $100 \%$. Dengan rincian, masing-masing dua orang penderita GGK termasuk ke dalam golongan anemia jenis berat dan ringan, serta 19 orang sisanya termasuk golongan anemia sedang.

Saran

1. Penderita penyakit GGK hendaknya melakukan pemeriksaan kesehatan secara rutin.

2. Dalam melakukan aktivitas, hendaknya penderita GGK tidak melakukan pekerjaan yang cukup berat.

3. Kebiasaan yang kurang baik seperti: merokok, minum kopi, teh, minum-minuman beralkohol, dan memakai narkoba, serta kebiasaan-kebiasaan buruk lainnya, hendaknya dihindari karena hal itu hanya akan menambah beban kerja ginjal. 
4. Agar kondisi tubuh dapat bertahan dengan baik, maka hendaknya penderita GGK mengkonsumsi makanan dengan gizi berimbang dan tidak berlebihan.

5. Penderita GGK hendaknya mengkonsumsi makanan yang banyak mengandung zat besi, dengan tujuan untuk membantu proses pembentukan sel darah merah.

\section{Daftar Pustaka}

Anderson Price, sylvia dan lorraine McCarty Wilson. 1983. PATOFISIOLIGi (Konsep-konsep klinik Proses-proses Penyakit). Jakarta: Kedokteran ECG.

Anderson Price 1985. PATOFISIOLIGi (Konsep-konsep klinik Proses-proses Penyakit). Jakarta: Kedokteran ECG.

Citrawathi, Maharta, Sutajaya. 2000. Anatomi dan Fisiologi Manusia. Singaraja: Jurusan Pendidikan Biologi.

Lumenta, Nico. A. dkk. 1992. Penyakit Ginjal. Jakarta: PT BPK Gunung Mulia

Murray, Robert. K. dkk. 1995. Biokimia Harper. Jakarta: Kedokteran EGC

Prodjosudjadi, Wiguno dan Aida Lydia. 2001. Penatalaksanaan Anemia pada GagalKronik_http://www.interna.or.id/interna/artikel/curent2001/cdt01_19.htm

Redana, I Wayan dan Siti Mariam. 2000. Biokimia II. Singaraj: Jursan Pendidikan Kimia.

Strayer, Lubert. 2000. Biokimia Edisi 4. Jakarta: Kedokteran EGC.

Winatasasmita, Djamhur. dkk. 1993. Biologi Umum. Jakarta: Universitas Terbuka. 